\title{
Ana Blandiana - Poemul în proză
}

Drd. KIȚU Daniel Universitatea „Dunărea de Jos” din Galați

Summary: Ana Blandiana's creation before the '90 covers two essential periods for the communist enclavisation of Romania: the opening to authentic cultural and spiritual values (1963-1997) and the Ceausescu's dictatorship (1977-1989). Therefore, it can be stated that the first area of Blandiana's creation is dominated by what was called the "resistance through culture" strategy. We will consider for our analysis a volume that saw the light of the printing in 1978, in the full dictatorship of Nicolae Ceausescu. It's about the "Most Beautiful of the Possible Worlds," a volume that captures the attention of the critic Mihai Zamfir for a species that is settled on the border between lyric and epic, namely the poem in prose. The critic places Ana Blandiana together with Geo Bogza in the category of writers who have leaned on this rare species in our literature, a species cultivated at the beginning of the last century, especially by George Bacovia. Mihai Zamfir realizes, at the species' level, a distinction between the "poem-definition" and the "involuntary poem". Ana Blandiana is framed in the first type of poem in prose, which is an "aphoristic and focused" text, by which the author "tries the poetical redefinition of the surrounding world." So, we will circumscribe the thematic areas of poems in prose, the symbolic constellations through which these areas are aesthetically exploited.

Key words: poem in prose, poem-definition, aphoristic, poetical redefinition, thematic areas

\section{Perspectiva critică asupra poemului în proză}

\section{I.1. Marginalii teoretice}

În lucrarea sa, Poemul românesc în proză, apărută în 1981, criticul Mihai Zamfir teoretizează mai întâi pe marginea conceptului, subliniind faptul că poemul în proză reprezintă „,registrul elevat al prozei literare” ${ }^{186}$. Criticul plasează într-o relație de opoziție poemul în proză și romanul: „Poemul în proză și romanul sunt hotarele netăgăduite ale unui sector literar în plină expansiune, așa cum se

\footnotetext{
186 Mihai Zamfir, Poemul românesc în proză, Ed. Minerva, București, 1981, p. 49.
} 
înfățișează proza unui veac pe care îl putem la fel de bine numi „al ficțiunii romanești” ca și „al istoriei” 187.

Mihai Zamfir punctează și trăsăturile narative care plasează într-o relație de opoziție cele două specii ale epicului. Astfel, în ceea ce privește romanul, autorul lucrării menționate evidențiază caracterul proteic al epicii romanești, alături de capacitatea acesteia de-a se modifica permanent prin noi motive, mai precis, versatilitatea estetică. Într-un anume fel, romanul poate fi definit ca o specie deschisă a epicului. Mihai Zamfir se referă, aici, la romanul realist de tip clasic.

În legătură cu poemul în proză, criticul subliniază, prin relație de opoziție, caracterul închis al construcției, redundanța motivică și un accent deosebit pe frazarea, îi spune acesta, melodică.

\section{I.2. Poemul românesc în proză}

În al doilea rând, criticul Mihai Zamfir atrage atenția asupra a două mari forme de realizare literară a speciei pe care le numește: poemul-definiție și poemul involuntar.

Scriitoarea Ana Blandiana este plasată, cu volumul Cea mai frumoasă dintre lumile posibile, în prima categorie, alături de nume precum Tudor Arghezi sau Geo Bogza. In cazul ultimului autor citat atenția criticului este reținută de volumul Paznic de far (1974).

Prin raportare la soarta acestei insolite specii a epicului în literatura noastră, Mihai Zamfir face niște considerații interesante.

Întâi de toate, autorul surprinde o realitate literară a epocii până la jumătatea deceniului al șaselea (1965): literatura se orientează către ceea ce criticul numește epic ostentativ:

În primii ani de după război, până prin 1950, în afară de opera lui Tudor Arghezi și de cea a lui Geo Bogza, proza poetică va fi slujită doar de câțiva suprarealiști tardivi (Gellu Naum) sau de câte un prozator liric silit să se refugieze în literatura pentru copii. După 1950, chiar și aceste câteva insule de proză poetică sunt înghițite de pseudo-epic; urmează aproape două decenii de epic ostentativ, în care orice inflexiune lirică va fi sever cenzurată. ${ }^{188}$

187 Ibidem.

${ }^{188}$ Mihai Zamfir, op. cit., p. 419. 
Poemul-definiție este configurat, din punctul de vedere al teoriei literare, ca un „text aforistic și concentrat”, care ambiționează „redefinirea poetică a lumii din jur" 189.

În viziunea lui Mihai Zamfir, un poem-definiție autentic se remarcă prin cristalizarea unei lumi coerente, „o variantă inedită a existenței." 190

II. Perspectiva critică asupra poemului în proză al Anei Blandiana

S-a stabilit, în general, faptul că perioada comunistă, care a marcat prima jumătate a traiectului creator al Anei Blandiana, a cunoscut trei perioade importante: stalinismul (1947 - 1963), epoca deschiderii, a întoarcerii către estetic și trecerea în plan secund a eticului (1963 - 1977) și dictatura ceaușistă (1977 - 1989). Ultimele două intervale de timp, contradictorii prin tendință, coincid cu prima parte a exersării poeticului de către Ana Blandiana. Sunt anii în care, deși s-a încercat, procesul de aneantizare culturală nu a reușit decât fragmentar, grație a trei factori umani ai rezistenței prin cultură: criticii literari, editorii și enclavizarea literaturii adevărate ${ }^{191}$.

Mircea Cărtărescu deosebește două categorii de scriitori: cei care au practicat compromisul politic și moral, cum este cazul unor nume afirmate în perioada interbelică, precum Tudor Arghezi, Mihail Sadoveanu sau Camil Petrescu, iar, pe de altă parte, scriitorii Generației '60, care se întorc spre valoarea estetică a literaturii. În această din urmă categorie, Cărtărescu o plasează pe Ana Blandiana, alături de Nichita Stănescu sau de Marin Sorescu ${ }^{192}$.

Textele din volumul Cea mai frumoasă dintre lumile posibile ale Anei Blandiana i se par criticului Mihai Zamfir „cea de a doua realizare majoră a poemului în proză contemporan" 193.

Autorul studiului remarcă frecvența formulei poemului despre poem în culegerea antologică a scriitoarei, cu alte cuvinte, a unor arte poetice implicite. În egală măsură, face o observație pertinentă cu privire la arhitectonica poemului în proză blandian:

\footnotetext{
189 Ibidem.

190 Ibidem.

${ }^{191}$ Mircea Cărtărescu, Postmodernismul românesc, Ed. Humanitas, București, 1999, p. 140.

192 Ibidem, pp. 140-141: „Nici un scriitor al acelor ani, oricât de valoros, nu se va mai putea impune cu naturalețea unor Nichita Stănescu, Marin Sorescu sau Ana Blandiana. Literatura intra definitiv într-un con de umbră și suspiciune."

${ }^{193}$ Mihai Zamfir, op. cit., p. 425.
} 
Constatăm de la început premisa dezvoltării arborescente a unei singure fraze, a unei singure impresii, uneori a unui singur cuvânt, care prin aprofundare strict poetică provoacă poemul în cauză" 194.

Mihai Zamfir relevă faptul că, în general, tehnica redactării unui asemenea tip de text, în cazul Anei Blandiana, constă într-o primă impresie, folosită ca element emergent al poemului propriu-zis. O caracteristică importantă a poemului în proză al Anei Blandiana o constituie „caracterul nominal al notației spontane” 195, piatra de temelie a unui asemenea tip de creație literară. După aceea poemul dezvoltă, mai mereu o stare de beatitudine, un admiratio permanent al frumuseților lumii, fie că vorbim despre peisajul autohton sau despre cel de aiurea. Această psihologie a primei impresii - după cum remarcă Mihai Zamfir - se regăsește în chiar coloana vertebrală a textului propriu-zis.

De asemenea, se observă rolul esențial în ceea ce privește mecanismul perceperii prin artă:

Să mai menționăm ascendentul pe care Arta îl are asupra realității, măsura în care pre-conceptul artistic influențează până și perceperea propriu-zisă a realității 196.

La nivel prozodic, criticul constată existența, invariabil, a unei unice frazetemă care, practic, structurează materia epică.

La nivel semantic, este identificată o regulă vizibilă de construcție a mesajului:

„Formularea acesteia ar suna astfel: autoarea vizează un adevăr general (de natură etică, de obicei) prin notarea unui banal detaliu concret al lumii din jur. Construcția acestor poeme ascultă de o specială geometrie spațială: detaliul concret, observat de obicei în prima fază a poemului, va proiecta în final o umbră imensă și disproporționată pe cerul adevărurilor generale, o umbră în care recunoști cu greu punctul de plecare." 197

$\mathrm{Cu}$ alte cuvinte, Mihai Zamfir observă punctul de plecare al textului, marcat la nivelul concretului și punctul terminus al acestuia, disproporționat abstractizant. Blandiana realizează astfel, mereu, o surprinzătoare trecere de la fenomenal la numenal ${ }^{198}$.

\footnotetext{
${ }^{194}$ Ibidem, p. 426.

195 Ibidem.

${ }^{196}$ Ibidem, p. 427

${ }^{197}$ Ibidem, p. 428

198 Ibidem.
} 
De asemenea, criticul apreciază în mod deosebit la stilul prozatoarei ceea ce el numește coborârea în peisajul interior al autorului. ${ }^{199}$

\section{Mnemotehnica maniheistă}

Într-un scurt text din volumul său antologic, Cea mai frumoasă dintre lumile posibile, intitulat Maniheism, Ana Blandiana postulează principiul esențial ce a dat naștere poemelor în proză din această carte, anume cel al rememorării, al amintirii:

Am observat că, pe măsură ce se așterne timpul, amintirile nu se șterg, ci își accentuează contrastele, pierd mulțimea nuanțelor și a tonurilor de gri pentru a păstra numai un ferm desen în alburi și negruri violente și exclusive. ${ }^{200}$

Autoarea textului subliniază caracterul tiranic al anamnezei ce o transformă în principiu mnemotehnic, ordonator ideatic al volumului de față.

În al doilea rând, Blandiana relevă că „pe măsură ce trece timpul amintirile devin maniheiste." ${ }^{201}$ Acest dualism structural gestiona estetic și corpusul poetic al operei autoarei, dar și ansamblul prozelor. Ana Blandiana este o artistă aspirând permanent către puritatea formei, către frumusețea lumii reiterând acel cunoscut principiu dostoievskian, reflectat în romanul său, Idiotul, prin intermediul personajului Mîșkin, conform căruia frumusețea ar trebui să salveze lumea, dar, în egală măsură, se vădește a fi un spirit ulcerat de realul imund, pervers și meschin. De aici se naște maniheismul viziunii sale artistice, relevabil și-n poemele în proză din Cea mai frumoasă dintre lumile posibile.

\section{III.1. Occident vs. Răsăritul românesc}

Din această perspectivă, spre exemplu, surprind textele care circumscriu experiențele călătoriilor pe care Ana Blandiana le-a întreprins, împreună cu Romulus Rusan, în Statele Unite ale Americii.

\footnotetext{
199 Ibidem., p. 430: „Un tur de forță al imaginarului se află în poemele unde același obiect va fi investit cu funcții sau semnificații opuse [...] aceeași opera de artă admirată la Cordoba, picture lui Ramiro de Torres, va executa mișcarea spiritual definitorie a autoarei, trecând de la vulgaritatea aparentă a concretului la nemurirea operei de artă propriu-zise. Și aceasta fără nicio schimbare a obiectului, numai prin reaccentuarea intensității privirii, prin " coborârea în peisajul interior » al autorului."

200 Ana Blandiana, Cea mai frumoasă dintre lumile posibile, Ed. Cartea Românească, București, 1978, p. 123.

201 Ibidem.
} 
Orașele americane, metropolele vizitate, stârnesc o reticență imediată și o tendință retractilă evidentă în sufletul ce se destăinuie în subtile poeme. New York, de pildă, lasă de la început impresia unei dezlănțuiri terifiante a betonului și a oțelului:

În dreapta apăruse Manhattan-ul. Priveliște pe care cu greu o puteai socoti de pe pământ, imaginație dezlănțuită morbid în beton, forță umană în care omul nu putea fi închipuit. ${ }^{202}$

Perspectiva profund subiectivă conturează, la nivel pur descriptiv, detaliile construcțiilor uriaș-amenințătoare, building-urile newyorkeze:

Coloane paralelipipedice, punctate de sute de șiruri de ferestre luminate rece și adormitor cu neon, suiau într-o apoteoză a pietrei amenințătoare în dimineața lânoasă. 203

Paradoxal, imageria ascendentă, care, la Blandiana, presupune, de regulă, îmbrățișarea transcendentului, sacralizare, evaziunea din realul claustrant și deformat spiritual, în acest text dezvăluie o fantasmatică și înspăimântătoare aglomerare urbană, ce dezumanizează și pietrifică spiritual: „blocurile se continuau ca niște fantasme întunecate și victorioase, nemaipărând să aparțină acestei lumi." 204

În aceeași întunecată sferă a percepției este plasată și metropola sudului american, Atlanta:

Am observat că, pe măsură ce se așterne timpul, amintirile nu se șterg, ci își accentuează contrastele, pierd mulțimea nuanțelor și a tonurilor de gri pentru a păstra numai un ferm desen în alburi și negruri violente și exclusive. ${ }^{205}$

În aceeași sferă a decepției imagistice este plasată și altă metropolă americană, Chicago. Blandiana este efectiv oripilată de „îngrămădirea urbană agresivă":

\footnotetext{
202 Ibidem., p. 26.

${ }^{203}$ Ibidem., p. 27.

204 Ibidem.

205 Ibidem., p. 123.
} 
Pe un frig capabil să împietrească cele mai frumoase sentimente, pe un vânt care zgâlțâia firmele făcându-le să pocnească năucitor, am rămas de la prima trecere prin Chicago cu impresia infiorătoare de îngrămădire urbană insalubră, înălțată probabil pentru uzul crimei, pentru că la ce altceva puteau servi imensele clădiri negre, ulcerate de fum, gangurile pustii semănate cu lăzi goale, cutii de gunoi părăsite și câini rebegiți? 206

Călătoria prin Chicago este înfățișată ca un veritabil descensus ad inferos. Ochiul Anei Blandiaana este rănit de urieșenia insalubră a buildingurilor americane.

Dacă e să ne raportăm la trăsătura distinctivă pe care Nicolae Manolescu i-o atribuia lui Călinescu, în amplul său eseu despre romanul românesc, Arca lui Noe, surprindem și în cazul Anei Blandiana „ochiul unui estet”, dar acel ochi însetat de frumos, care acum înregistrează cu acuitate acea tendință de urâțire exterioară a lumii de peste ocean.

Spre deosebire de New York-ul prins în arabescul patimii de-a sufoca lumea însăși în beton și oțel, Atlanta apare jugulată de propria încremenire-ncăpățânată în Istorie:

Insăși decăderea orașului era datorată - se pare - realizării, ani și decenii de-a rândul, a creditelor federale, yankee. Un oraș utopic, degradat de nostalgie, drapat în faldurile unui trecut de eroice erori sfâșiate de realitatea triumfătoare, un oraș de zgârie-nori stingheri și de ruine dezorientate, printre pajiști și mesteceni bucolici ca dinaintea războiului de secesiune. ${ }^{207}$

Celălalt versant al maniheismului mnemotehnic din poemele în proză ale Anei Blandiana dezvăluie o ființă însetată de frumos, copleșită nostalgic de amintiri pe care le ordonează voit într-o paradigmă a desăvârșirii estetice. Cele mai multe, dintre aceste amintiri faste, luminoase sunt cele stârnite de plaiurile mioritice.

Încântarea și farmecul sunt conturate poetic în cuvintele despre un sat aproape atemporal din zona Ţării de Sus:

Există atâtea feluri de tristețe încât unele dintre ele pot fi confundate $\mathrm{cu}$ fericirea. Cum altfel s-ar putea numi sentimentul care ne purta năuciți de admirație pe ulițele întroienite ale acestui sat în care trăise o bunică a lui Creangă și una a lui Labiș? 208

Dacă imaginile citadine americane instituiau o distanță între percepția privitorului și peisajul rece și anost, în acest caz, este evidentă simbioza afectivă cu tărâmul primordial al unei ruralități cufundate în anistoric. Blandiana relevă astfel, prin impresiile sale de călătorie, ciocnirea inerentă între civilizația Occidentului și cultura Răsăritului, care include și peisajul autohton:

\footnotetext{
206 Ibidem., p. 83.

${ }^{207}$ Ibidem., p. 48.

208 Ibidem., p. 71.
} 
$\mathrm{Cu}$ pereții intens vineții decupați de priveliștea imaculată, fiecare casăadăpostită sub o mare căciulă de zăpadă, cu margini de lemn lucrat cu migală și geniu, părea în egală măsură o capodoperă și o făptură vie, caldă, respirând. 209

Zgârie-norilor inerți, artificiali, total lipsiți de pulsația vieții din peisajul american le sunt opuse aceste bojdeuci țărănești din spațiul românesc, respirând o căldură profund umană.

La fel, și imaginea Voronețului din același poem, Prin Țara de Sus, dezvăluie o vitalitate caldă, molcomă, ce împresoară ireversibil sufletul autoarei:

Crescută deodată, violentă aproape, din omătul scânteietor, mănăstirea era atât de vie, încât părea o halucinație, un vis colorat cu obsesia albastrului, un vis cum visezi după mari fericiri. ${ }^{210}$

Singura soluție de salvare din impresia de claustrare și dezamăgire stârnite de mediul citadin este întunericul. Precum la Blaga, și în cazul Anei Blandiana întunericul este generator de mister. Presimțirea nopții estompează contururile și diluează caracterul prea net și sever al construcțiilor urbane:

Între timp se făcea întuneric și, când ieșeam, orașul nu mai semăna cu cel pe care-1 întrezărisem. Țipetele luminoase ale reclamelor decupau alte priveliști decât razele resemnate ale asfințitului, felinarele cu neon puneau alte accente, mai extravagante, în discursul patetic al străzilor. ${ }^{211}$

\section{Psihologizarea cadrului exterior}

Putem observa, în cazul Anei Blandiana, o tendință evidentă de interiorizare a elementelor cadrului exterior. Redescoperim același ochi semnificativ, iubitor al detaliilor semnificative. Scriitoarea manifestă mereu tendința de-a izola un aspect, un amănunt din spectacolul mundan, care i se înfățișează și de a-1 drapa în dantelăria fanteziei sale poetice. Subiectivizarea perspectivei exterioare echivalează cu transformarea acesteia într-un peisaj secund, un fel de joc barbian de-a metamorfozarea prin artă.

Trebuie menționat că, la modul platonician, Blandiana distilează din real aspectele semnificative pentru tabloul conturat estetic în volumul său, exact la ceea ce face trimitere titlul cărții, Cea mai frumoasă dintre lumile posibile. Cititorul este

\footnotetext{
209 Ibidem.

210 Ibidem., p. 72.

211 Ibidem., p. 74.
} 
invitat în acest paradis livresc, rod al fanteziei creatoare, teritoriu imaginar, construct creator.

Imaginația autoarei poemelor în proză este predominant vizuală. Este impresionată de imaginea crengilor înflăcărate-ntr-un apus autumnal care dă, înainte de toate, impresia de forță copleșitoare:

La Huşi toamna era atât de puternică, încât nu părea o toamnă trecătoare printr-un oraș, ci un oraș trecător printr-o toamnă. Casele, străzile, aproape nu se mai vedeau în lumina orbitoare a frunzelor. Curțile erau numai ruguri mari peste jăratecul cărora se înălțau siluete patetice de arbori, orașul ar fi putut pleca fără ca nimic să se clintească în arhitectura crengilor, fără ca nimic să se schimbe în planurile toamnei. ${ }^{212}$

În orizontul francez, de această dată - la Menton - ploaia este colerică. Blandiana are intuiția descoperirii permanente, în acea procesualitate poetică, dincolo de care se așterne mereu verbul ei indicibil, a senzualității naturii, acel fel de-a se copilări al soarelui italian: Colerică, ploaia se consumase. Norii începeau să se ridice, descoperind senzual, ca de după cortine groase de pluș, creste de munți, orașe. Italia își strălucea copilărește în soare acoperișurile roșii și pereții albi ai Ventimigliei. ${ }^{213}$

Un drum de întoarcere spre București se transformă într-un fantasmatic traiect printr-o realitate imediată, dacă e să ne raportăm și la Max Blecher.

Pentru Blandiana orice detaliu al exteriorității devine pretext de metamorfozare poetică a cufundării întru frumos. Ceața, în acest caz (exemplul este fragmentul intitulat $A c a s \breve{a})$, devine labirint al spaimei și-al voluptății de-a încerca necunoscutul: Undeva, nu prea departe, știam că era Bucureștiul, undeva nu prea departe erau străzile, capabile să taie tunele abia luminate, și zidurile, capabile să fragmenteze văzduhul, și gurile de canal, capabile să topească aureolele de abur ale pământului, undeva nu prea departe știam că există orașul cu arbori și case, care se văd și între care te simți în siguranță, dar noi înaintam pipăind înspăimântați cu botul mașinii cerul alb coborât printre noi, pierduți în universul amenințător, de lână. 214

Negru pe alb surprinde imaginea unei păduri contrastând vizual într-un mod violent cu albul omniprezent al zăpezii:

În albul acela perfect, abia întrerupt de albul răzleț al mestecenilor, trenul a descoperit deodată o pădure, o pădure adevărată, desenată virulent cu negru,

\footnotetext{
212 Ibidem., p. 142.

${ }^{213}$ Ibidem., p. 132.

${ }^{214}$ Ibidem., p. 124.
} 
încâlcită de crengi, de tulpini și rădăcini, care străpungeau și învingeau zăpada întrun contrapunct plastic hotărât și plin de o forță rea, contrazicătoare. ${ }^{215}$

Același text conține și o confesiune indirectă a autoarei, ce definește într-un mod sugestiv maniheismul viziunii acesteia despre lume: Era, probabil un protest al realului care nu se lăsa prea mult covârșit de ideal; era, probabil, o dovadă, pe care nu o cerusem, că lumea nu e perfectă; sau era numai un punct de comparație care mi se oferea altruist ca să nu încetez să mă mir și să nu mă obişnuiesc vreodată cu frumusețea care cuprinde și topește în sine urâtul, așa cum nesfârșita câmpie de nea și-a reluat curgerea după terminarea pădurii, înglobate cu înțelepciune $\hat{\imath}$ univers. 216

Sufletul poetic sedus permanent de frumosul lumii se-ncăpățânează să spere că acesta va avea mereu ultimul cuvânt de spus în această lume efemeră.

\section{BIBLIOGRAFIE}

Blandiana, Ana, Cea mai frumoasă dintre lumile posibile, Ed. Cartea Românească, București, 1978.

Cărtărescu, Mircea, Postmodernismul românesc, Ed. Humanitas, București, 1999.

Zamfir, Mihai, Poemul românesc în proză, Ed. Minerva, București, 1981.

${ }^{215}$ Ibidem., p. 41.

216 Ibidem. 